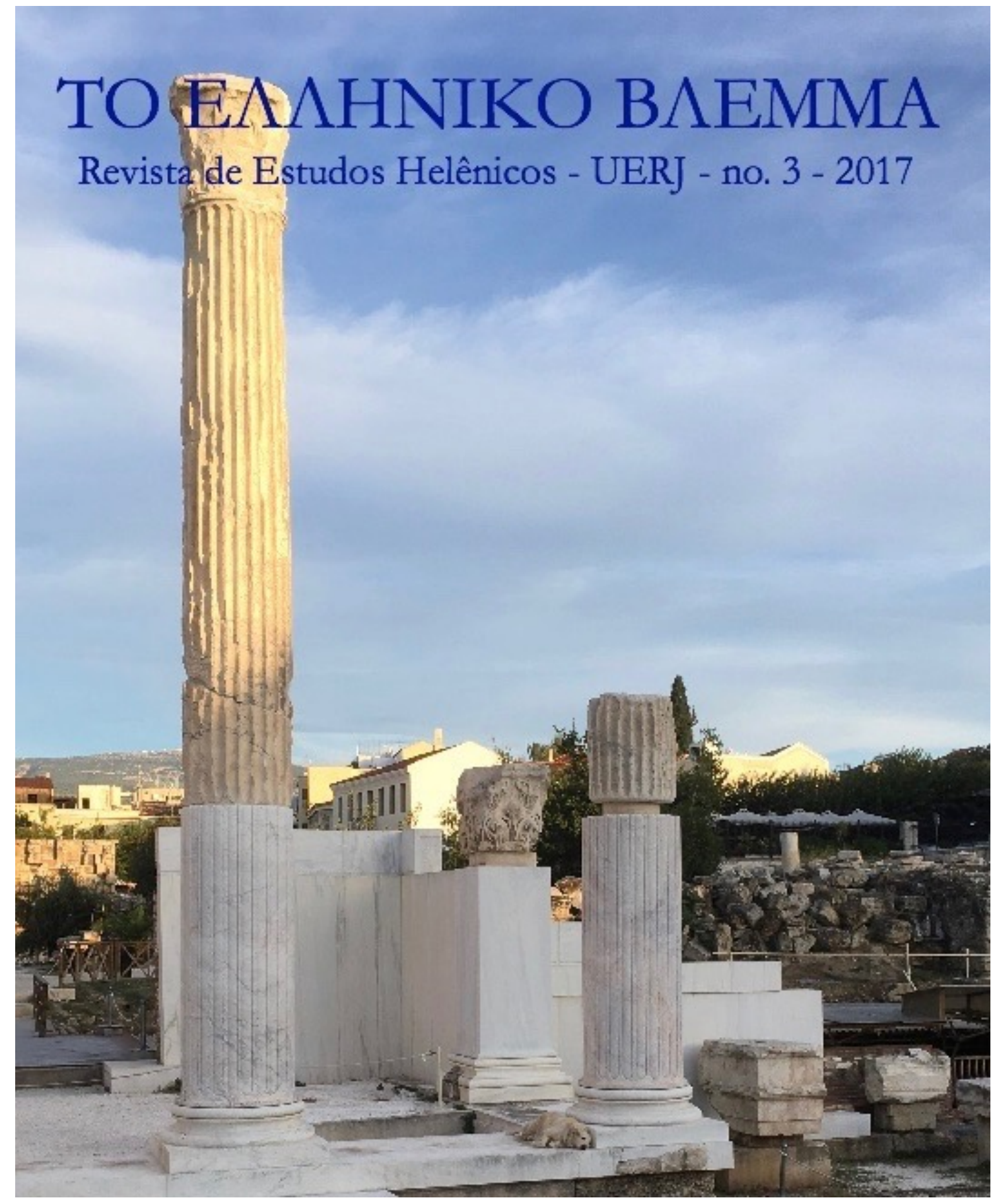




\title{
KATERINA GÓGOU COMO PERSONA: ELEMENTOS AUTO-BIOGRÁFICOS NA FICCIONALIZAÇÃO DE UMA AUTORA POLÍTICAMENTE ENGAJADA
}

\author{
Nicolas Pelicioni de Oliveira - UNESP
}

\begin{abstract}
Resumo: Os poemas de Katerina Gógou (1940-93) ambientam-se no contexto político da Grécia dos anos 1970-90, isso significa que a poetisa pôde ter como pano de fundo para sua obra as lutas dos grupos anarquistas da época. Escrevendo a partir da perspectiva de um narrador anárquico que vive e se opõe à politica opressora vigente, Gógou aderiu aos ideais ainda hoje mantidos por

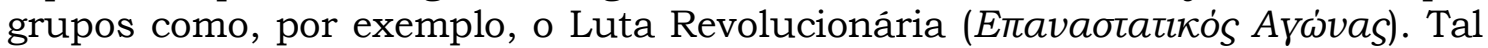
posicionamento político articulado com um procedimento narrativo que ficcionaliza o autor, parece ter autorizado uma leitura biografista e referencial; no entanto, essa leitura é bastante redutora da criação poética gogueana. $O$ presente artigo tem por fim analisar esse procedimento à partir de uma ótica que valorize a escolha narrativa, uma vez que, em termos poéticos, se um autor ficcionalalizado aceita os riscos de uma leitura biografista, posteriormente paga pela ousadia dessa transgressão, ainda que tal procedimento tenha ampliado de modo significativo as possibilidades interpretativas do texto.
\end{abstract}

Palavras-chave: Katerina Gógou; contracultura; anarquismo; persona poética.

\section{KATERINA GOGOU AS PERSONA: AUTOBIOGRAPHICAL ELEMENTS IN THE FICTIONALIZATION OF A POLITICALLY ENGAGED AUTHOR}

Abstract: The poetry work of Katerina Gogou (1940-93) is set down in a context of 1970-90's political Greece, in a way that the author could have as a background for her poetry the struggle of the anarchist's ideal of the time. Writing from a point of view of an anarchist narrator who lives and faces the oppressive political system, her poetry adhere to the ideals that are kept even today by the anarchist groups, as, for example, the Revolutionary Struggle

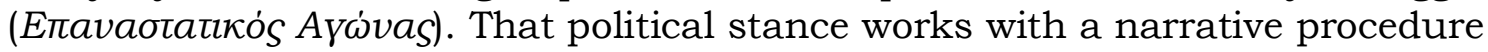
that fictionalise the author and, consequently, it seems to have authorised a biographical criticism; nevertheless, this criticism reduces Gogou's poetical creation. The aim of the present paper is to analyse that procedure from a point of view that optimise the narrative choice, once, in poetics, a fictionalised author may accept the risk of a biographical criticism and also pays for this transgression in the end, even if the procedure has amplified significantly the textual possibilities.

Keywords: Katerina Gogou; counterculture; anarchism; persona. 
Katerina Gógou (1940-93), ateniense, trabalhou como atriz tanto no teatro quanto na televisão e cinema, até que escolhesse dedicar-se exclusivamente à literatura. Publicou as obras Três cliques esquerdos (Toia $\kappa \lambda$ ik

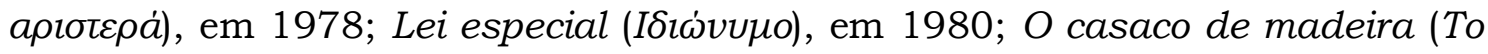

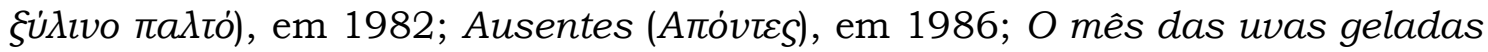

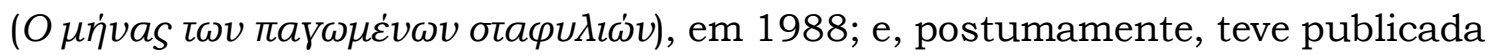

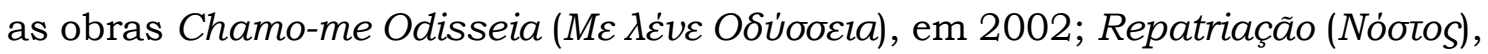
em 2004; e as obras completas Agora veremos o que vocês vão fazer (Tópa va

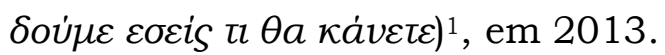

Por ser uma atriz de sucesso, Gógou era uma personalidade muito conhecida na Grécia, consequentemente, numa primeira leitura de seus poemas é fácil entender que sua obra foi escrita, predominantemente, com um caráter documental conjugado a elementos facilmente identificáveis como autobiográficos. Por consequência, sua poética estaria intimamente ligada ao momento político pelo qual passava a Grécia nas décadas de 1970-90. Importante lembrar que nesses anos de escritura poética a Grécia, apesar de sua história e de situar-se na Europa, era apenas uma democracia nascente que ainda se via oprimida por autoridades militares e que tentava iniciar seu caminho rumo à uma integração com a Europa moderna. Isso significa que o país aderia aos valores europeus no que se refere ao capitalismo e, como afirma Demetriou (2015, p. 69), essa transformação produzia "dois tipos de violência: uma que provém de instituições soberanas e outra do terrorismo anti-estatal2", consequentemente, surgiram grupos minoritários dissidentes reivindicando direitos.

Os poemas parecem ligar-se não só ao momento político, mas também ao momento cultural vivido na Europa. Tome-se como exemplo as vanguardas europeias, em especial o Surrealismo. Por essa ótica, os poemas de Katerina Gógou buscariam a emancipação total do ser humano por meio da fuga da lógica, da razão, da inteligência crítica, da pátria, da moral e da religião. Em sua feitura, teríamos, como aponta Teles (2012, p. 215), “a recorrência à magia, ao ocultismo, à alquimia medieval", e tentativas de voltar ao momento anterior ao da corrupção social, como ilustra o poema $160^{3}$, de Repatriação:

\footnotetext{
1 Todas as traduções de poemas e títulos de Katerina Gógou são minhas em parceria com Anthee Bezioula. 2 Tradução minha a partir do original inglês.

3 Poucos dos poemas gogueanos são identificados pelo título, o mais frequente é a numeração. Mirtô Tássiou, filha de Katerina Gógou, deteve os direitos da obra da mãe depois que esta morreu e cuidou da edição das
} 


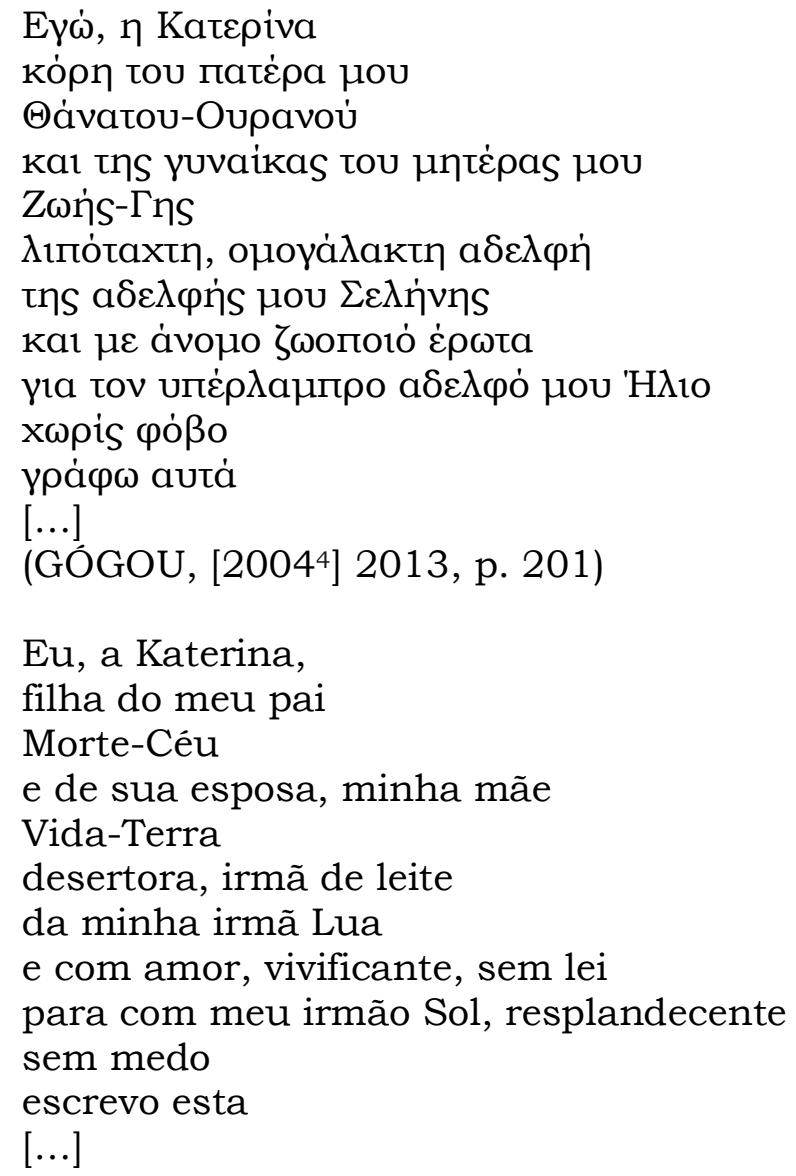

Katerina Gógou faz parte da contracultura e há sim elementos do Surrealismo em sua poética. Ainda seguindo a definição de Teles (2012, p. 217), o Surrealismo, depois de 1925, apresenta a conscientização política pela qual seus representantes pretendiam "levar a poesia à ação: de método de investigação do subconsciente, a poesia ia passar a instrumento de agitação social, refletindo por certo os ecos da revolução comunista de 1917”. Esse mesmo entusiasmo pela agitação político-social encontrada no Surrealismo é também um elemento constituinte da chamada subcultura europeia. Assim entende, por exemplo, Hebdige (2002, p. 105), ao associar características surrealistas ao movimento Punk londrino. Ora, o primeiro livro de Katerina

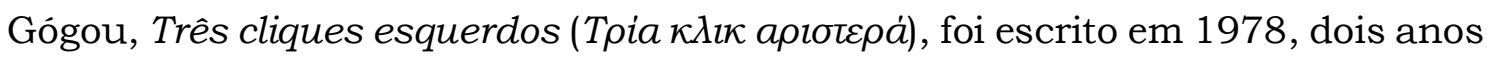

obras completas intensificando a tendência ao sistema de numeração e atualizando os poemas de acordo com a nova ortografia grega; isto é, passou-os do sistema politônico para o monotônico. Mantenho neste trabalho a mesma numeração proposta por Mirtô Tássiou na reunião Agora veremos o que vocês vão fazer (2013), contudo, nas citações também indico ano e página.

${ }^{4}$ Deixo entre colchetes a data de primeira edição para que seja mais fácil a localização histórica ou até mesmo a localização da obra individual, uma vez que utilizo as obras completas. Mais adiante, quando a citação grega for colocada entre colchetes, é a data de primeira edição que estará entre parênteses. 
após o movimento Punk ter tido sucesso em Londres. Mesmo que Katerina não tenha recebido influência direta desse movimento, suas motivações - produzir uma arte capaz de aborrecer a classe dominante - certamente eram similares.

Contudo, apesar do período histórico e da intensa atividade política, Gógou não perde a dimensão do poético. Por conseguinte, sua persona vive em uma Grécia ficcional que faz intersecção com o mundo político grego que rodeia a poetisa. Como exemplificado mais acima, Gógou escreve seus poemas em primeira pessoa. Isso, no entanto, não é tudo, pois a voz poética gogueana é uma personagem feminina chamada Katerina Gógou, coincidentemente, também nascida no dia $1^{\circ}$ de junho e que deu à luz uma filha, que chamou Mirtô Tássiou. Essa voz poética coincide com o posicionamento político da autora, ambas anarquistas, feministas, marxistas, trotskistas, poetisas e suicidas. Em outras palavras, o que Gógou fez foi ficcionalizar o autor, consequentemente, essa persona Katerina Gógou confunde-se com a poetisa Katerina Gógou, especialmente porque, como fora mencionado, os poemas apresentam-se como relato histórico de teor autobiográfico.

Como afirma Brandão (2005, p. 152) em referência ao narrador romanesco, a narrativa em primeira pessoa é de grande complexidade, no sentido em que "o mais comum (falar como si mesmo) nada mais é que o auge da complexidade mimética (na medida em que eu sempre represento o que sou)". Essa falta de distanciamento deixa ao leitor a interpretação e o julgamento das ações.

Tal procedimento não é corriqueiro em poesia, mas é possivel identificalo em outros poetas. Como exemplo, temos o Poema de sete faces, de Carlos Drummond de Andrade, no qual nos é apresentado uma persona chamada Carlos: "Quando nasci, um anjo torto / desses que vivem na sombra / disse: Vai, Carlos! ser gauche na vida" ([1930] 2015, p. 10), coincidentemente, o autor do poema tem o mesmo nome que o autor empírico, e, por essa coincidência, que Antonio Candido denomina "uma espécie de exposição mitológica da personalidade" (1970, p. 68), a voz que sofre pode confundir-se com a do autor que a inscreveu no poema. Uma vez dissociados, é possivel entender que essa persona denominada Carlos é o homem em geral, não um escritor em particular - em que pese, quanto ao 'homem em geral', a paráfrase feminina de Adélia Prado, também uma persona inscrita no conhecido poema Com licença poética: 
"Vai ser coxo na vida, é maldição pra homem. / Mulher é desdobrável. Eu sou." ([1975] 2015, e-Pub).

A persona Katerina Gógou coloca-se ora como vítima das mais diversas brutalidades, como, por exemplo, sofrendo violência física (poema 113 de $O$ mês das uvas geladas: "Eu via meu corpo / os estudantes / como experiência /

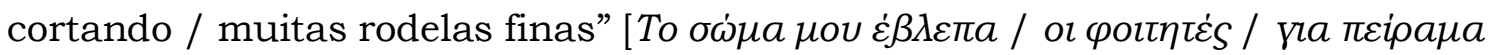

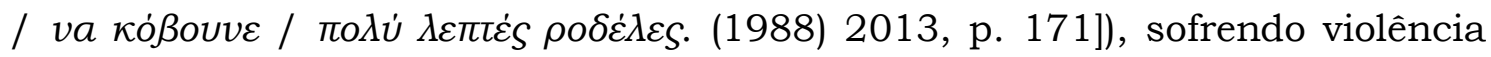
moral (poema 142 de Repatriação: "Abrem a minha geladeira. Tiram as fotografias da gaveta. Pegam os poemas que eu escrevi e dizem que são deles

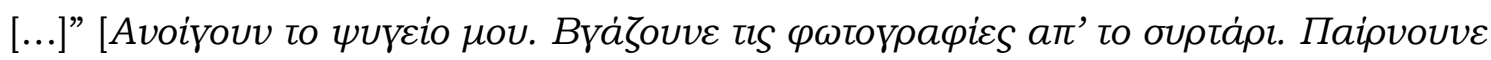

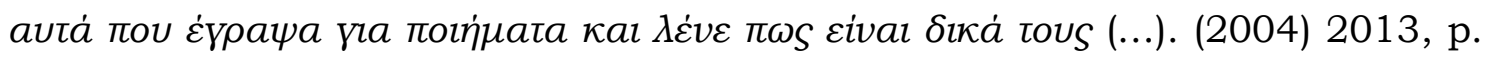
187]), sofrendo violência sexual (poema 151 de Repatriação: “[...] depois que eu

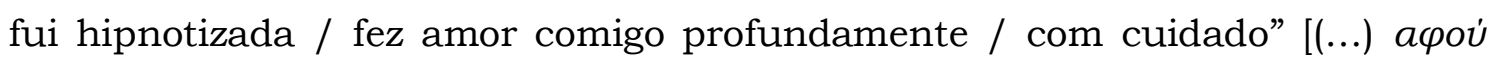

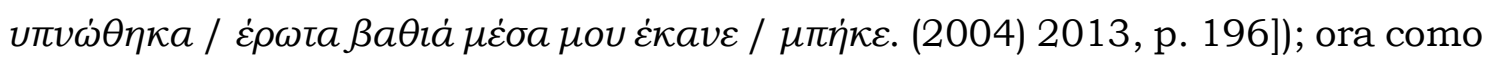
algoz (poema 145 de Repatriação: "Nas noites, com um saco, saltamos os muros dos cemitérios e juntamos os gatos mortos. Vendemos no Propileu ou

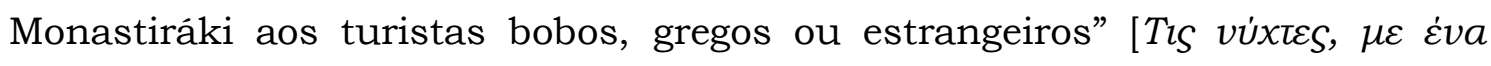

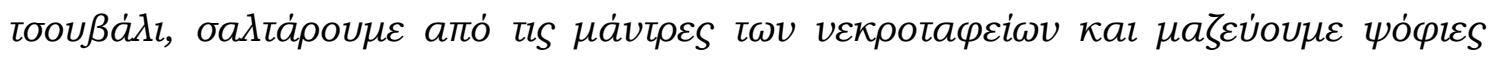

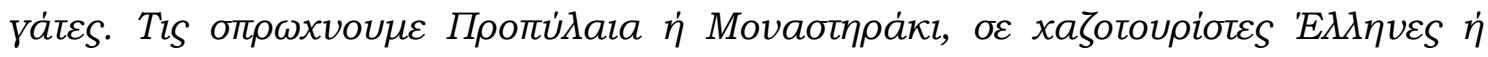
§̇́vous. (2004) 2013, p. 190-1]); ora como observadora apenas (poema 18 de Três cliques esquerdos: "Levantou-se com cuidado / pegou o fio elétrico da assadeira

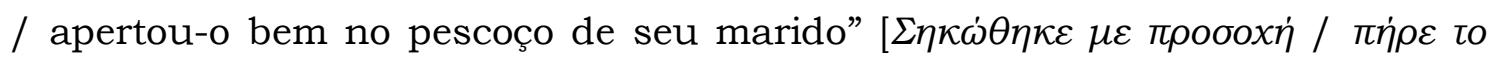

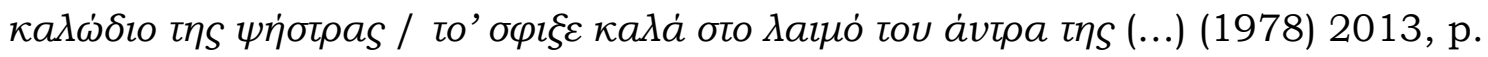
33]).

A atividade politica intensa da poetisa junto ao movimento anarquista grego teve desdobramentos em sua obra poética. O grupo anarquista junto ao qual atuou politicamente muda de nome de tempos em tempos e atualmente é

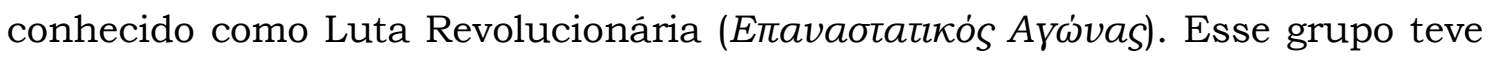

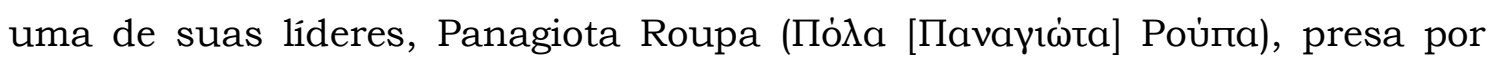
terrorismo no dia cinco de janeiro de 2017. O fato teve repercussão internacional, sendo noticiado, por exemplo, pelo jornal Norte Americano The New York Times, com a manchete Greece's Most-Wanted Terrorist Is Arrested in Athens Suburb (A mais procurada terrorista grega é presa nos subúrbios de Atenas). Apesar de as manifestações nos dias de hoje terem sua conotação violenta muito intensificada pela denominação "terrorismo", a própria poetisa 
faz uso da palavra em seus poemas. Lembra, contudo, que as manifestações ocorem como resposta a várias outras formas de violência:

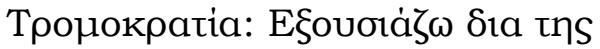

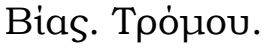

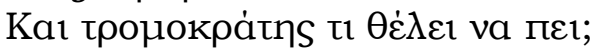

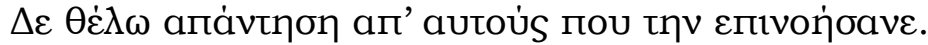

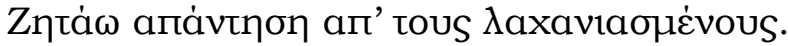

(GÓGOU, [1988] 2013, p. 179)

Terrorismo: Domínio através da

Violência. Terror.

E terrorista quer dizer o quê?

Não quero a resposta dos que a inventaram.

Peço a resposta dos sem fôlego.

Na Grécia, a manifestação anarquista do dia 17 de novembro de 1985, resultou na morte de cinco manifestantes, dentre eles o adolescente Michael

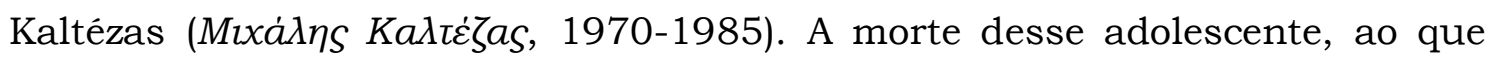
parece, causou uma forte impressão na poetisa. Cinco de seus oito livros foram publicados em vida, sendo que o último deles, além de reunir toda obra poética, é acrescentado de poemas inéditos. O episódio envolvendo Michael Kaltézas é mencionado em duas das obras póstumas, em Chamo-me Odisseia ([2002] Me

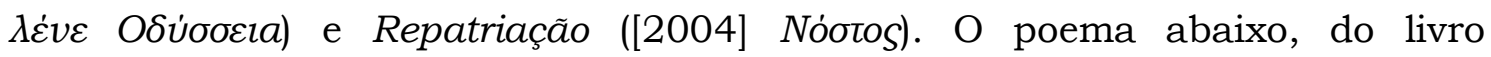
Repatriação, refere-se ao episódio que vitimou Kaltézas, inserindo-o nominalmente junto aos outros quatro manifestantes também assassinados:

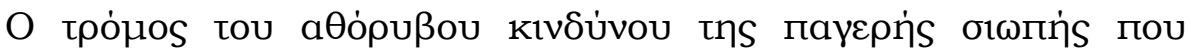

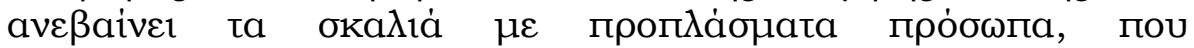

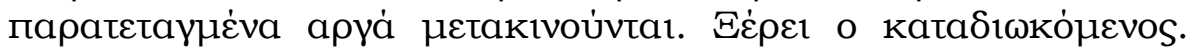

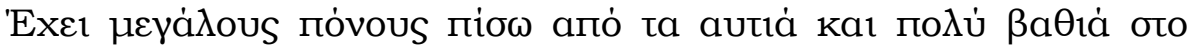

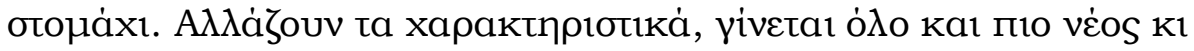

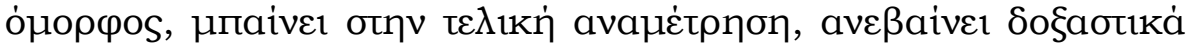

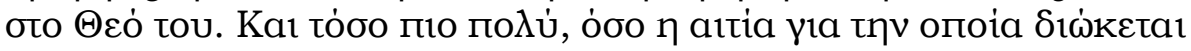

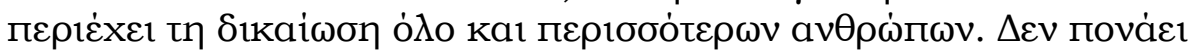

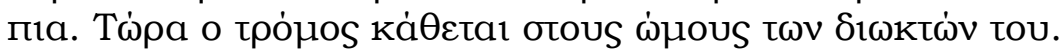

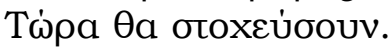

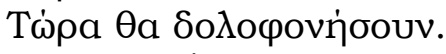

$\Delta$ oגoøovoúv.

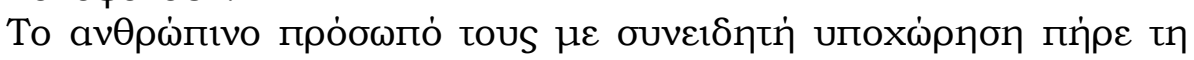

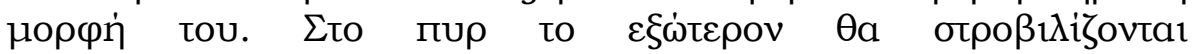

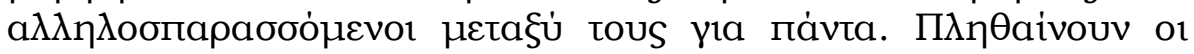

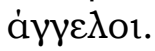


(GÓGOU, [2004] 2013, p. 186)

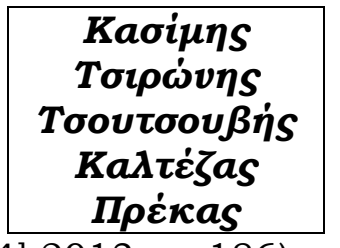

O terror do perigo silencioso, do silêncio gélido que sobe as escadas com rostos amalgamados que se põem em forma lentamente e deslocam-se. Conhece o procurado. Tem grandes dores atrás das orelhas e muito profundamente no estômago. As características mudam, ele torna-se ainda mais novo e bonito, entra na disputa final, sobe gloriosamente ao seu Deus. E então, justamente, o motivo de sua autuação contém toda a redenção dada pela maior parte das pessoas. Não dói mais. Agora o terror repousa sobre os ombros de seus perseguidores. Agora farão pontaria.

Agora assassinarão.

Assassinam.

Seu rosto humano, com a deliberação da retirada, retomou sua beleza. Vão se contorcer uns sobre os outros para sempre no fogo do inferno. Aumentam os anjos.

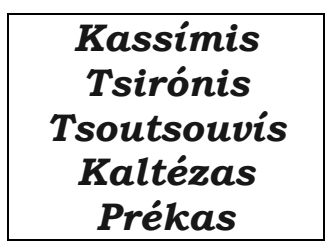

A persona Katerina Gógou coloca-se pelas ruas e bairros de Atenas, em especial a periferia (está associada especialmente ao bairro Exarchia [Eß́axeıı]), e apresenta-se como andarilha, guerrilheira, drogada, revolucionária, artista sempre ao lado da classe operária e da população oprimida, que é compreendida, por exemplo, por imigrantes legais ou ilegais. As principais temáticas de sua obra poética são a loucura, a solidão, a morte, a traição. Ressalte-se que, se por um lado, analisar sua obra como biográfica é redutor, por outro lado também será redutora uma análise que ignore as condições nas quais os poemas foram produzidos.

Seria preciso recorrer a uma análise da recepção para explicar o que significa uma leitura biografista ou literária de um poema. Contudo, de modo sucinto, uma advertência quanto aos riscos de reduções consequentes a uma ou outra abordagem pode ser retirada do poema de Ana Cristina Cesar, Correspondência completa, texto no formato de carta que apresenta dois leitores equivocados em suas intransigências: 
Fica dificil fazer literatura tendo Gil como leitor. Ele lê para desvendar mistérios e faz perguntas capciosas, pensando que cada verso oculta sintomas, segredos biográficos. Não perdoa o hermetismo. Não se confessa os próprios sentimentos. Já Mary me lê toda como literatura pura, e não entende as referências diretas. (CESAR, [1979] 2013, p. 50)

Há muita subjetividade em um narrador de primeira pessoa, afinal, mesmo as "referências diretas" são estratégias que conduzem o leitor à determinada interpretação. Seria preferivel acreditar que Gógou, em seu processo de ficcionalização do autor, apresenta em sua poesia suas atitudes políticas conformando sua obra à realidade política de seu país. Por meio dessa estratégia, sua militância se faz presente mesmo nos poemas mais delicados, como, por exemplo, o poema 133 de O mês das uvas geladas. Neste há um jogo

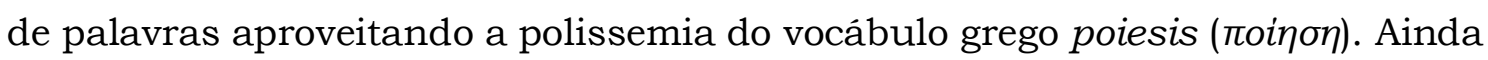
que seja possivel uma "transcriação poética", como sugere Haroldo de Campos, uma tradução que aproveite a semântica do termo "poesia" será um trabalho de grande habilidade artística. Por esse motivo, apresento o poema em grego, sem a tradução, pois assim será possível discutir o vocabulário e o sentido poético sem que seja necessário justificar soluções tradutórias:

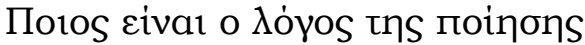

поن่ ßyaive1 aп' то поเம்

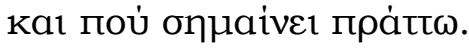

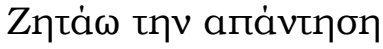

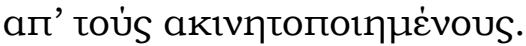

(GÓGOU, [1988] 2013, p. 186)

Se a lingua portuguesa, com mil anos de afastamento, torna-se outro idioma com outra denominação e outra localização geográfica, a língua grega, com dois mil anos de recuo, ainda será grego - grego antigo, grego bíblico, mas sempre grego. Desse modo, Gógou tem toda a fortuna literária grega à sua disposição, e, como afirma Guimarães Rosa em entrevista a Lorenz, "Cada palavra é, segundo sua essência, um poema, só em sua gênese” (1991, p. 89). Dada a importância cultural do idioma grego para o ocidente, certo elemento lexical ou morfológico pode, por si só, resultar em poesia, como é exemplo o poema acima. 
Tanto em grego moderno quanto em grego clássico, a raiz do vocábulo "poesia" está presente na formação de substantivos e também de adjetivos e de verbos. Jacyntho Lins Brandão expõe de modo sucinto, em trabalho sobre o que a antiguidade clássica entendia por poesia, uma análise desse vocábulo que será útil para o entendimento do poema de Gógou:

[...] se Homero e Hesíodo não conhecessem os termos poietés (nome do agente), poiesis (nome da ação) e poíema (nome do resultado da ação), conhecem o verbo poieín, fazer, cujos significados têm impacto nas noções posteriores do poeta enquanto fazedor ou produtor da poesia como feitura ou produção e do poema como feito ou produto. (BRANDÃO, 2015, p. 22)

Todo o vocabulário posto em discussão no poema 133 é obtido a partir da palavra poesia, notadamente, nos termos expostos por Brandão. A tradução literal, aproveitando a explicação de Brandão, seria "Qual o sentido da poíesis

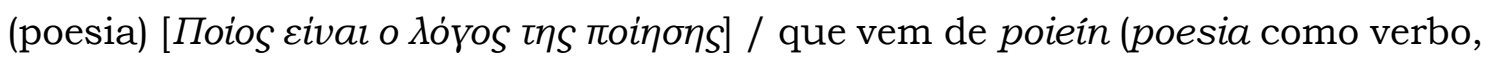

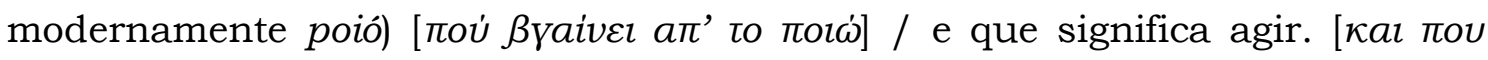

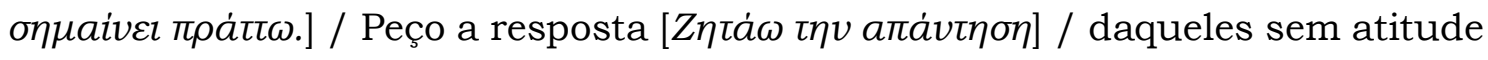

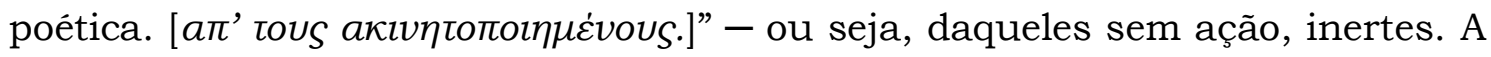
persona exige, com esse poema, o engajamento politico por parte dos poetas, pois não é admissivel que se permaneça inerte frente ao cenário político vigente em sua época.

Por fim, é preciso apontar alguns aspectos formais da poesia gogueana que também contribuem para o direcionamento de certo tipo de entendimento interpretativo. São peculiares alguns dos poemas do livro Chamo-me Odisseia

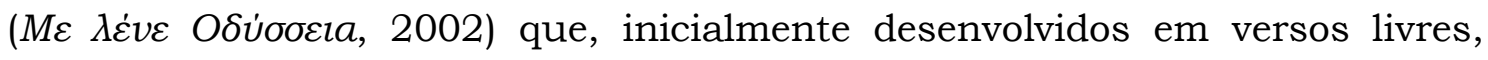
posteriormente foram inseridos no interior de poemas em prosa de extensão maior. Segundo a biógrafa Spyratou (2007, p. 42-3), o livro Chamo-me Odisseia, embora póstumo, estava pronto para ser publicado quando a poetisa morreu, portanto, é duvidoso que a instabilidade da forma deva-se à incompletude do poema, embora sejam possiveis especulações a respeito das escolhas que Gógou teria feito - se morrera antes de uma opção definitiva, em prosa ou em verso.

O poema que exemplifica essa dualidade foi escrito após a internação de Gógou em um hospital psiquiátrico para desintoxicação devido ao uso de drogas. A poetisa o considerava uma autobiografia poética, embora acreditasse 


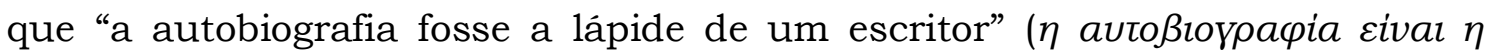

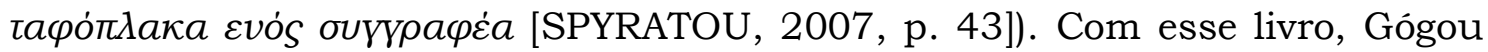
teve sua primeira tentativa de lidar com a prosa, uma forma que favorece o caráter biográfico. O título, "Unidade para acidentes graves, Dafni?" (pronúncia oxítona), diz respeito a clínicas médicas. A "Unidade para Acidentes Graves" correspondente à nossa UTI; "Dafni", por sua vez, é um famoso hospital de Atenas para atendimento psiquiátrico, como é o Bezerra de Menezes - em grego, pode-se dizer de alguém que age como louco, que é um caso para o Dafni; assim como em português se diz que é um caso para o Bezerra.

Apenas o procedimento poético é do interesse da presente análise e os textos, embora não sejam curtos, são apresentados na íntegra para possibilitar a comparação. Primeiro o texto em verso, que posteriormente será inserido no texto maior, em prosa:

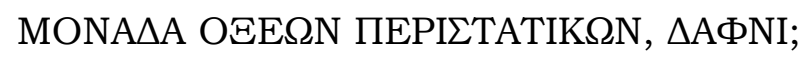

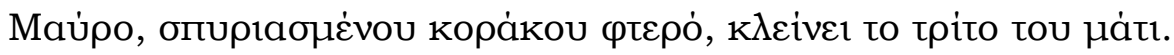

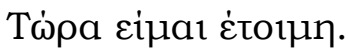

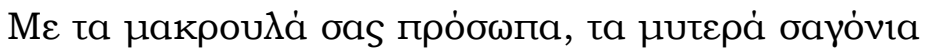

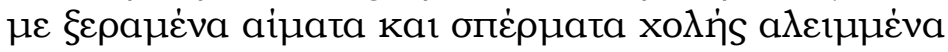

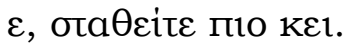

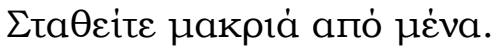

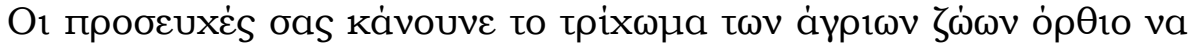
otغ่keta1

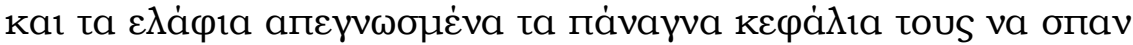

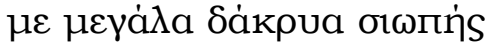

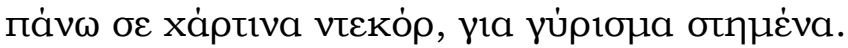

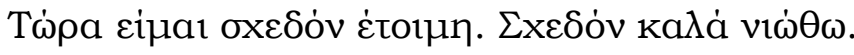

Autós o прóגoyos

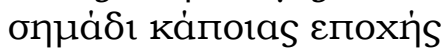

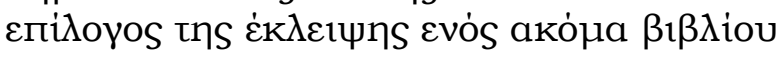

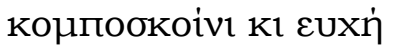

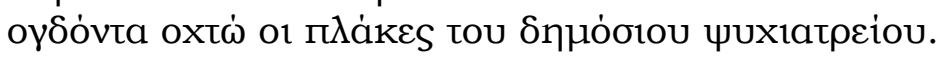

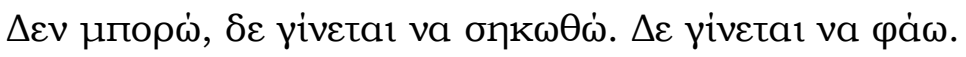

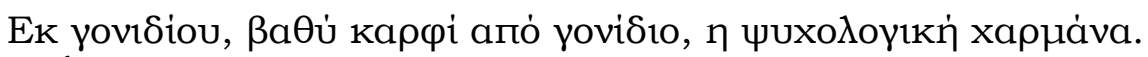
(GÓGOU, [2002] 2013, p. 233-4) 


\section{UNIDADE PARA ACIDENTES GRAVES, DAFNI?}

Negro, pena de abutre borbulhante, fecha a sua terceira visão.

Agora estou pronta.

Com os seus rostos alongados, os queixos pontiagudos com sangues ressecados e espermas de bílis untadas eh, fiquem mais para lá.

fiquem longe de mim.

As suas orações fazem a pelagem dos animais ferozes ficar de pé

e os cervos a quebrar desesperadamente as suas cabeças imaculadas

com grandes lágrimas silenciosas

sobre decorações de papel, postas para a rodagem do filme.

Agora estou quase pronta. Quase me sinto bem.

Esse prólogo

sinal de uma época qualquer

epílogo da eclipse de mais um livro

rosário e benção

oitenta e oito - as placas do Hospital Público de Psiquiatria.

Não posso, não é possível me levantar. Não é possivel comer.

Devido aos genes, profundo prego dos genes, a psicologia misturada.

Esse poema, bastante típico dentre as temáticas gogueanas - solidão, loucura, morte, traição -, também é típico quanto à forma: versos livres ligados pelo enjambement. Páginas adiante, no mesmo livro, estão os mesmos versos em forma de prosa, explicitando, por assim dizer, o enjambement, e a sensação de relato pessoal. Os grifos são meus, tanto em grego quanto em português, e explicitam os versos repetidos do texto anterior:

\section{NA `АI ПЕРНФАNН ГІА MENA}

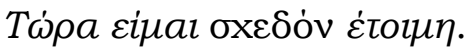

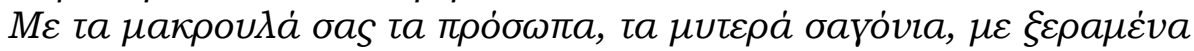

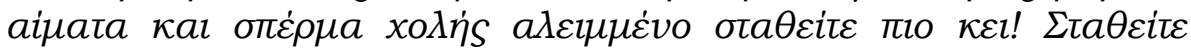

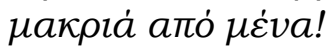

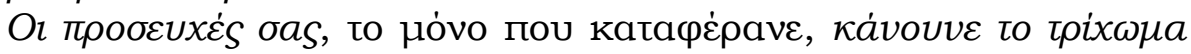

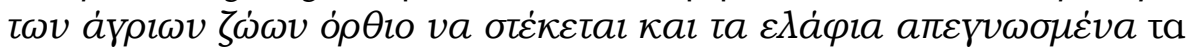

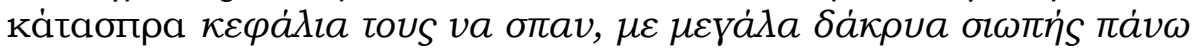

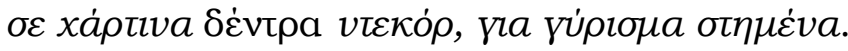




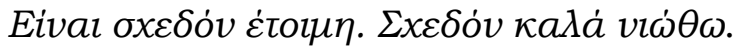

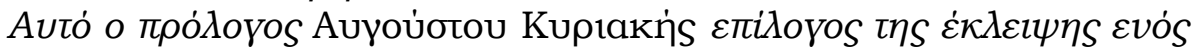

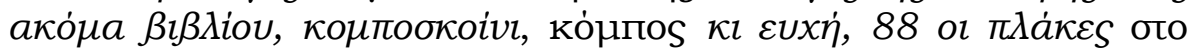

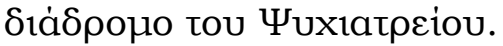

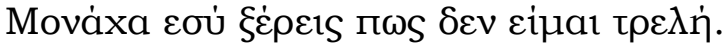

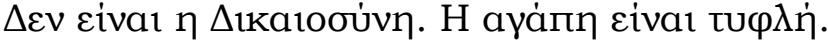

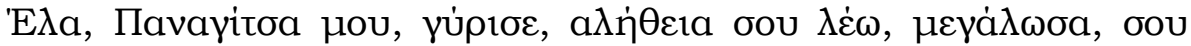

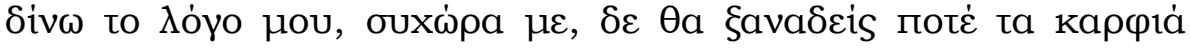
Hou...

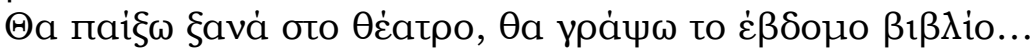

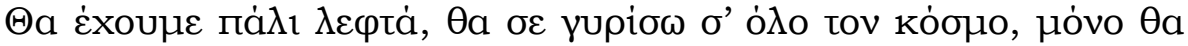

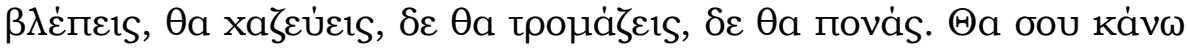

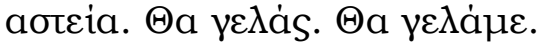

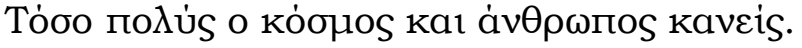

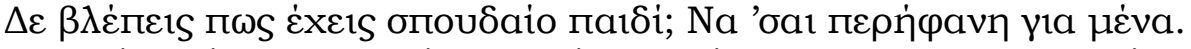

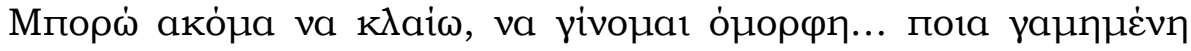
xпреia;

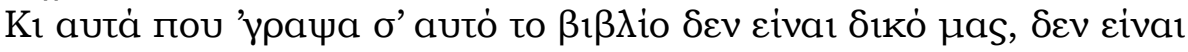
ò̀o yra uas.

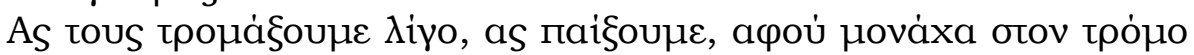

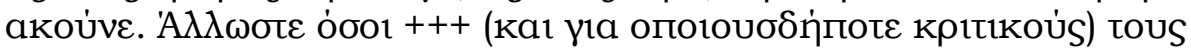

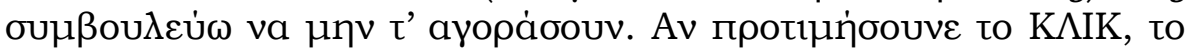

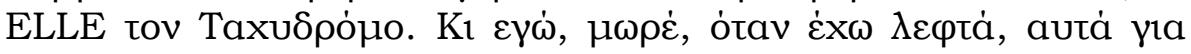

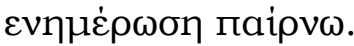

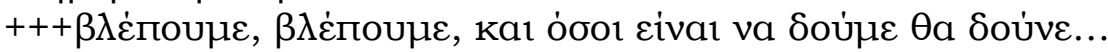

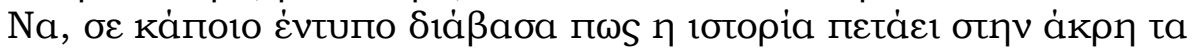

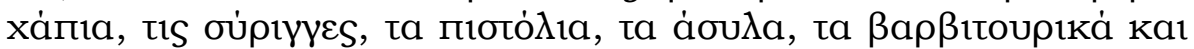

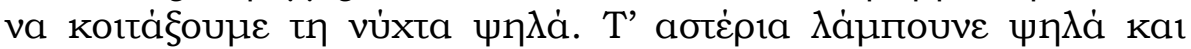

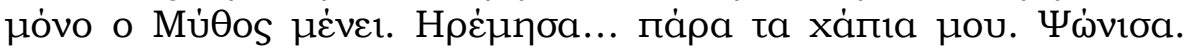

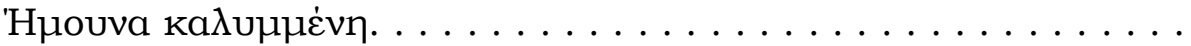
$\ldots \ldots \ldots \ldots \ldots \ldots \ldots \ldots \ldots$

(GÓGOU, [2002] 2013, p. 258-60)

Katepiva

\section{TENHA ORGULHO DE MIM}

Agora estou quase pronta.

Com os seus rostos alongados, os queixos pontiagudos com sangues ressecados e esperma de bilis untado, fiquem mais para lá! Fiquem longe de mim!

As suas orações, a única coisa que conseguiram, fazem a pelagem dos animais ferozes ficar de pé, e os cervos a quebrar desesperadamente as suas cabeças branquíssimas com grandes lágrimas silenciosas sobre decorações de árvores de papel, postas para a rodagem do filme.

Está quase pronta. Quase me sinto bem. 
Esse prólogo de domingo de agosto, epílogo da eclipse de mais um livro, rosário, nó e benção, 88 as placas do corredor do departamento de Psiquiatria.

Só você sabe que não estou louca.

Não é a Justiça. O amor é cego.

Vai, minha Virgem Santa, volte, a você digo a verdade, já cresci, dou a você minha palavra, perdoe-me, não verás nunca mais os meus pregos...

Atuarei de novo no teatro, escreverei o sétimo livro...

Teremos dinheiro de novo, levarei você pelo mundo todo, você verá! Você vai se descontrair, não terá susto, não vai doer. Vou fazer piadas com você. Você rirá. Riremos.

Tão grande a multidão e nenhum humano.

Não vê como você tem uma criança excepcional? Tenha orgulho de mim. Ainda posso chorar, ficar bonita... Que merda de química?

E isso que escrevi nesse livro não é só nosso, não é tudo sobre nós.

Vamos assustá-los um pouco, vamos atuar, pois eles só ouvem no terror. Além disso, todos os que +++ (e para qualquer um dos críticos) aconselho-os a não o comprarem. Se preferem o CLIQUE, o ELLE, o Carteiro. E eu, cara, quando tenho dinheiro, pego estes pela informação.

+++ vemos, vemos, e aqueles que são para ver, verão...

Eis, numa revista qualquer li que a história deixa para o lado as pílulas, as seringas, as pistolas, os asilos, os barbitúricos e se olharmos na noite acima. As estrelas brilham acima e é só o Mito que fica. Acalmei-me... tomei as minhas pílulas. Comprei.

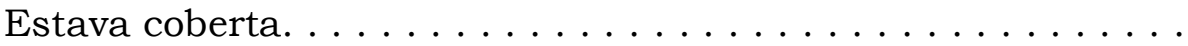
mamãe?

Katerina

"Clique" refere-se a seu primeiro livro Três cliques esquerdos (os cliques dizem respeito ao ajuste da mira de um fuzil), livro que ganhou tradução para o inglês e por isso é o mais lembrado dentre a produção gogueana. Importante notar que o texto, em primeira pessoa, é também assinado, traz o nome Katerina 
ao final. Há outros poemas apresentados como cartas, com data e localização de envio, como é o caso do poema 168 - um dos poucos poemas nomeados -, este, embora escrito em versos livres, dirige-se com intimidade a um interlocutor anônimo:

\section{$\mathrm{E} \Delta \Omega$ 'H A $\Lambda$ OY}

Аүаппนе่ve.

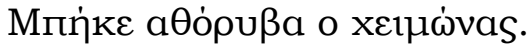

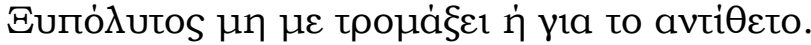

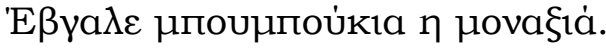

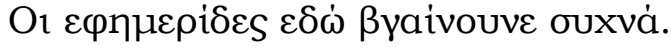

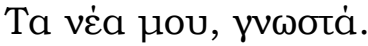

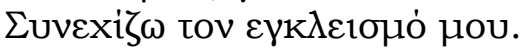

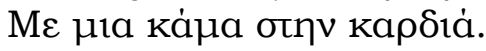

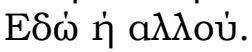

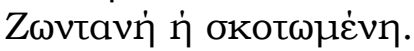

Аүапп

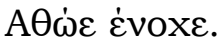

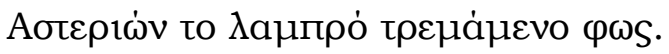

Bia, appovia.

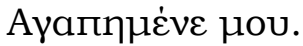

(GÓGOU, [2002] 2013, p. 217-8)

\section{AQUI OU NOUTRA PARTE}

Amado.

Entrou discretamente o inverno.

Descalço para não me assustar ou pelo contrário.

A solidão brotou flores.

Os jornais aqui saem com frequência.

As minhas notícias, conhecidas.

Continuo meu isolamento.

Com um punhal no coração.

Aqui ou noutro lugar.

Viva ou morta.

Amado.

Culpado inocente.

Brilho de luz trêmula das estrelas.

Violência, harmonia.

Meu amado. 
A poesia de Katerina Gógou vem sendo descoberta, já conta com a biografia de Spyratou e algumas poucas críticas, dentre estas a de Demetriou (2015), que analisa a participação da poetisa junto ao grupo anarcoterrorista da Grécia da pós-ditadura com o artigo “'Eu defendo o anarquismo.' A desconstrução da autoridade ou a mitificação do terrorismo na Metapolitefsi grega: a poesia de Katerina Gógou." Como afirma Demetriou (2015, p. 69)

Apesar de sua popularidade e das sucessivas reimpressões de sua obra, que confirma a evidência de seu sucesso, especialmente entre leitores com inclinação às políticas de esquerda, ela é omitida dos compêndios da literatura neohelênica de Mario Vitti, e Noderick Beaton, ou mesmo de extensivos estudos dedicados à poesia da geração dos anos 1970 por críticos como Kostas Papayiorgiou, Alexis Ziras e Karen Van Dick5. Além do mais, com poucas exceções, ela permaneceu ausente das antologias dos anos que se seguiram à sua morte6. Uma monografia recente dedicada a ela, por Agape Virginia Spyratou levantou certo interesse por seu trabalho, mas a falta de crítica especializada é ainda significativa.

De fato, Gógou não faz parte do cânone literário grego e talvez nunca faça, afinal, não ajudou a estabelecer o idioma grego no período moderno, como fez Kaváfis, não fez reflexões filosóficas como Kazantzákis, nem alcançou o lirismo de Odysseu Elytis. Muito diferente disso, como se ouve no álbum $\mathrm{Na}$ rua ( $\Sigma$ to $\Delta \rho o ́ \mu o, 1981)$, Katerina por vezes grita seus versos sobre um fundo musical roqueiro, em tom panfletário e tem como preocupação a denúncia da barbárie da ditadura militar. No entanto, a militância politica não é a única chave para a leitura dos poemas gogueanos, se em $O$ mês das uvas geladas (1988), os poemas fazem órbita ao nascimento de sua filha, sendo temas a gestação, o parto, a criança, são também temas o desejo de morte e a violência de um

\footnotetext{
${ }^{5}$ Tradução minha a partir do original inglês. As obras estão listadas abaixo na sequência em que foram mencionadas:

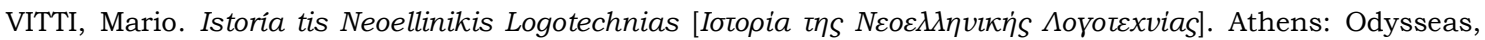
2003. (História da literatura neo-helênica, compilação originalmente italiana, Storia della letteratura neogreca, cuja primeira edição data de 1971 [N.T].)

BEATON, Roderick. An Introduction to Modern Greek Literature. Oxford: Clarendon Press, 1994. (Uma introdução à literatura da Grécia moderna [N.T.].)

PAPAYIORGIOU, Kostas. I genia tou '70 [H yevviá tou '70]. Athens: Kedros, 1989. (A geração de 1970 [N.T.])

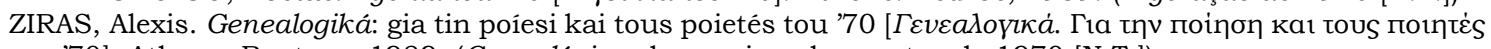
tou '70]. Athens: Roptron, 1989. (Genealógico: da poesia e dos poetas de 1970 [N.T.])

VAN DYCK, Karen. Kassandra and the Censors: Greek Poetry Since 1967. Ithaca/London: Cornell University Press, 1998. (Cassandra e os censores: a poesia grega desde 1967 [N.T.])

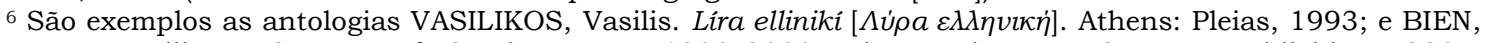
Peter et alii, A Century of Greek Poetry, 1900-2000. River Vale, NJ: Cosmos Publishing, 2004. (respectivamente, Lira grega e Um século de poesia grega, 1900-2000 [N.T.].)
} 
Estado ditador e, não obstante, o leitor é levado por um caminho tortuoso, como se tudo fosse relato pessoal. Justamente esse engodo, proposital, pode ter sido responsável pela rejeição de seus poemas por parte da crítica.

\section{Referências}

BRANDÃO, Jacyntho Lins. A invenção do romance. Brasília, DF: Editora da UNB, 2005.

BRANDÃO, Jacyntho Lins. Antiga musa: arqueologia da ficção. Belo Horizonte, MG: Relicário, 2015.

CANDIDO, Antonio. Inquietudes na poesia de Drummond. In: Vários escritos. São Paulo: Duas Cidades, 1970.

CESAR, Ana Cristina. Poética. São Paulo: Companhia das Letras, 2013.

DEMETRIOU, Demetra. I Defend Anarchism: Deconstructing Authority or Mythicizing Terrorism in Greece's Metapolitefsi: The Poetry of Katerina Gogou. In: Forum for Modern Language Studies: The Journal of Literary, Cultural and Linguistic Studies from the Middle Ages to the Present. Volume 51, Issue 1. Oxford: Oxford University Press, January 2015, p. 68-84.

GÓGOU, Katerina. Tóra na doúme eseís ti tha kánete: poiémata 1978-2002.

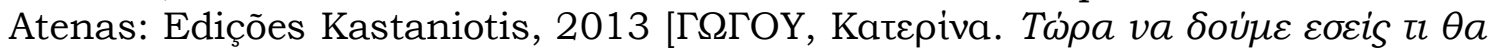

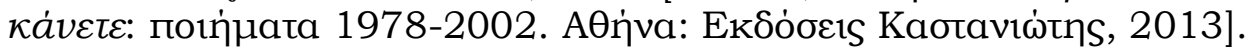

HEBDIGE, Dick. Subculture: the meaning of style. London and New York: Taylor \& Francis e-Library, 2002.

LORENZ, Günter W. Diálogo com Guimarães Rosa. In: COUTINHO, Eduardo F. (org.). Guimarães Rosa. 2ª ed., Rio de Janeiro: Civilização Brasileira, 1991.

SPYRATOU, Agape Virginia. Katerina Gógou: érotas thanátou. Atenas, Grécia:

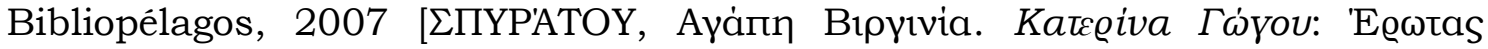

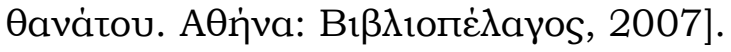

TELES, Gilberto Mendonça. Vanguarda europeia e modernismo brasileiro: apresentação dos principais poemas metalinguísticos, manifestos, prefácios e conferências vanguardistas, de 1857 a 1972. Rio de Janeiro, RJ: José Olympio, 2012. 